\title{
Survei Populasi Nyamuk dalam Kandang Babi di Kelurahan Walian Kota Tomohon Sulawesi Utara
}

\author{
Albert J. Podunga* \\ aJurusan Produksi Ternak, Fakultas Peternakan, Universitas Sam Ratulangi
}

K A T A K U N C I

Genera, Nyamuk, Babi

\begin{abstract}
A B S T R A K
Nyamuk adalah salah satu jenis ektoparasit yang sering dijumpai dan dapat menyebabkan kerusakan kulit, penurunan produktivitas, dan penularan media penyakit. Studi nyamuk di kandang babi Kota Tomohon dilakukan dengan tujuan untuk menentukan keragaman dan kepadatan populasi dan waktu aktivitas nyamuk (Culicidae) di kandang babi. Metode pengamatan dalam penelitian ini yaitu mengumpulkan nyamuk setiap 2 (dua) jam dengan menggunakan Light Trap yang ditempatkan di setiap kandang mulai pukul 18.00-06.00. Hasil penelitian menunjukkan bahwa keanekaragaman nyamuk ditemukan dalam 3 genera, yaitu Culex, Anopheles, dan Armigeres. Kepadatan populasi nyamuk berhasil tertangkap 546 individu nyamuk yang terdiri dari Culex 356, Anopheles 182, dan Armigeres 8. Penelitian ini juga mendapatkan bahwa Culex memiliki kelimpahan genus nyamuk tertinggi. Ditemukan bahwa kelimpahan tertinggi 225 (63\%) dari Culex pada jam 22.00-24.00. Waktu aktivitas nyamuk tertinggi diperoleh dari data jumlah tangkapan nyamuk terbanyak.

\section{A B S T R A C T}

Mosquitoes are one type of ectoparasites that are often encountered and can cause skin damage, decreased productivity, and transmission of disease media. The study of mosquitoes in the pig barns of Tomohon City was carried out with the aim to determine the diversity and population density and the time of mosquito activity (Culicidae) in the pig barns. The observation method by collecting mosquito every 2 (two) hours at the Light Trap placed in each cage starting at 18.00-06.00 is used in this study. The results of the study showed that the mosquitoe diversity were found in 3 genera, namely Culex, Anopheles, and Armigeres. The population density of mosquito barn was found 546 individuals of mosquitoes consisting of Culex 356, Anopheles 182, and Armigeres 8. This research also indicates that Culex have highest abundance of mosquitoes genera. It was found that the highest abundance 225 (63\%) of Culex at 22.00-24.00. The highest activity time of mosquitoes obtained from the data of the highest number of mosquito catches.
\end{abstract}

K E Y W O R D S

Genera, Mosquitoe, Pig

TERSEDIA ONLINE

31 Oktober 2019

\section{Pendahuluan}

Proses terjadinya penyakit tular vektor di suatu daerah meliputi 3 faktor utama, yaitu: (a) adanya penderita, baik dengan gejala klinis ataupun tanpa gejala klinis; (b) adanya nyamuk atau vektor dan (c) adanya manusia yang sehat. Penyakit yang ditularkan oleh vektor hingga kini masih menjadi masalah kesehatan masyarakat di Indonesia dengan angka morbiditas dan mortalitas yang cukup tinggi dan berpotensi menimbulkan kejadian luar biasa (KLB). Menurut Peraturan Menteri Kesehatan Republik Indonesia No.374/MENKES/PER/III/2010, vektor didefinisikan sebagai arthropoda yang dapat menularkan, memindahkan dan/atau menjadi sumber penularan penyakit terhadap manusia.

Golongan penyakit bersumber nyamuk masih merupakan masalah kesehatan masyarakat yang penting di Indonesia. Penyakit-penyakit tersebut antara lain: malaria, demam berdarah dengue (DBD) dan filariasis. Jenis-jenis nyamuk yang menjadi

\footnotetext{
${ }^{*}$ Corresponding author: Jurusan Produksi Ternak Fakultas Peternakan Universitas Sam Ratulangi, Jalan Kampus Unsrat; Email address: albertjootjep@unsrat.ac.id Published by FMIPA UNSRAT (2019)
} 
vektor utamanya adalah Aedes sp., Culex sp., Anopheles sp. dan Mansonia sp.

Nyamuk termasuk ke dalam ordo Diptera, famili Culicidae, dengan 3 subfamili yaitu Toxorhyncitinae (Toxorhyncites), Culicinae (Aedes, Culex, Mansonia, Armigeres) dan Anophelinae (Anopheles). Di seluruh dunia, dilaporkan terdapat sekitar 3200 spesies dari 39 genus (Mallis, 2004). Anopheles, Culex, Aedes, Mansonia, Armigeres, Haemagogus, Sebethes, Culiseta dan Psorophara adalah genus nyamuk yang menghisap darah manusia dan berperan sebagai vektor penyakit. Beberapa jenis nyamuk dapat dijumpai di mana-mana seperti Culex quinquefasciatus dan Aedes aegypti yang bersifat cosmopolitan (Sigit H. S., dkk. 2006), merupakan vektor atau penular utama dari penyakit-penyakit arbovirus, seperti: demam berdarah dengue (DBD), Chikungunya, demam kuning, Japanese Encephalitis serta penyakit yang disebabkan nematode misalnya filariasis dan penyakit yang disebabkan oleh protozoa darah seperti malaria.

Dalam usaha pengendalian penyakit yang ditularkan oleh serangga (Arthropod Born-Disease), perlu diketahui spesies serangga penular (vektor), ekologi serangga dan keadaan dari suatu daerah. Penyakit Japanese Encephalitis adalah salah satu penyakit viral asal nyamuk yang dapat ditularkan ke manusia dan hewan. Siklus penularan virus JE adalah dari nyamuk ke babi, babi ke nyamuk kemudian nyamuk ke manusia. Ternak babi telah diketahui dapat berperan sebagai "amplifier" dan "reservoir" virus JE, di mana virus JE di dalam tubuh babi (viremia) mengalami perbanyakan dan babi merupakan sumber penularan (Lubis, 1990).

Dalam menetapkan vektor tersangka di suatu daerah dapat ditentukan berdasarkan hasil laporan bahwa jenis-jenis nyamuk dimaksud di daerah lain positif sebagai vektor. Nyamuk dapat disebut sebagai vektor potensial bila di daerah tersebut dan di daerah lain belum terbukti sebagai vektor virus $\mathrm{JE}$, tetapi telah mempunyai sifat yang dimiliki oleh vektor antara lain kelimpahan nisbi dan frekuensi tertangkap yang tinggi, menyebar, dominan, mempunyai kepadatan populasi yang tinggi, banyak berkontak fisik dengan manusia dan hewan (anthropozoofilik). Penelitian ini bertujuan untuk melihat keragaman genus dan kepadatan nyamuk dalam kandang ternak babi yang berpotensi sebagai vector penyakit viral Japanese encephalitis.

\section{Material dan Metode}

Penelitian ini dilakukan di kandang ternak babi yang berlokasi di Kelurahan Walian Kota Tomohon, Sulawesi Utara. Waktu penelitian selama 2 bulan, dimulai pada bulan Maret hingga April 2019.

\section{Observasi Nyamuk}

Penangkapan nyamuk dilakukan dengan menggunakan 2 unit perangkap nyamuk (Light Trap) yang dipasang selama 12 jam, sejak pukul 18.00 sampai pukul 06.00. Setiap 2 jam, jala perangkap diganti dengan jala yang baru. Pergantian jala perangkap nyamuk dilakukan setiap 2 jam sehingga mendapatkan 6 data jumlah nyamuk tertangkap dalam 12 jam pemasangan light trap. Pengangkapan nyamuk dilakukan 3 kali ulangan, selang waktu 2 minggu. Nyamuk yang tertangkap dipindahkan kedalam wadah/botol plastic dan diberi label: tanggal dan jam penangkapan. Selanjutnya, nyamuk tertangkap di bawa ke laboratorium untuk diidentifikasi sampai tingkat genus.

\section{Analisa Data}

Penelitian ekplorasi populasi nyamuk dalam kandang ternak babi mendapatkan data yang dianalisis secara deskriptif untuk mengidentifikasi keragaman genus nyamuk tertangkap. Nyamuk diidentifikasi secara morfologi.

Kepadatan atau kelimphan nyamuk dihitung berdasarkan jumlah nyamuk yang tertangkap setiap 2 jam. Jumlah nyamuk (berdasarkan genus) yang paling banyak, merupakan kepadatan atau kelimpahan genus nyamuk yang paling tinggi. Hal ini menunjukkan aktivitas tertinggi bagi genus nyamuk tertentu.

\section{Hasil dan Pembahasan}

Peternakan babi yang bhabitat yang erlokasi di Kelurahan Walian Kota Tomohon, berada pada 1,3371어; $124,8137^{\circ} \mathrm{BT}$, dengan ketinggian 854,5 dpl. Jarak antara kandang dengan pemukiman cukup berdekatan, sekitar 100 meter. Vegetasi disekitar kandang ditanami tanaman perkebunan seperti jagung, sayur kubis dan tumbuhan bambu pada sisi kandang lainnya. Suhu di dalam kandang selama penlitian dilakukan berkisar $26^{\circ} \mathrm{C}$ hingga $32,5^{\circ} \mathrm{C}$ dan kelembaban dalam kandang berkisar $56 \%$ hingga $66 \%$. Kondisi ini cukup ideal bagi habitat perkembangbiakan nyamuk.

Sistim peternakan yang masih didominasi oleh peternakan rakyat yang pemeliharaannya berdekatan dengan pemukiman, sangat mendukung siklus penularan penyakit yang bersifat zoonosis seperti Japanese encephalitis. Habitat atau tempat perkembangbiakan nyamuk atau tempat-tempat peristirahatan nyamuk, seperti: persawahan, kolamkolam, genagan air, saluran air, sudut-sudut kandang yang lembab dan limbah ternak, merupakan kondisi yang ideal untuk perkembangan nyamuk. 


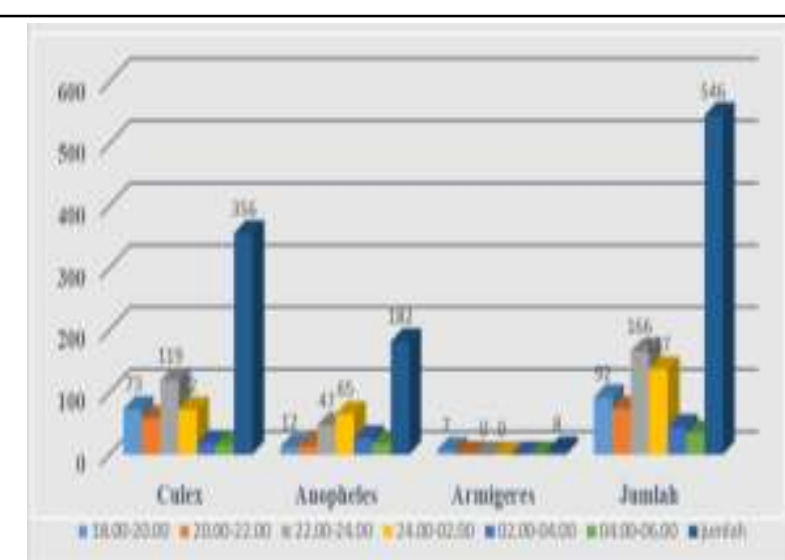

Gambar 1. Grafik Keragaman dan Kelimpahan Populasi Nyamuk dalam Kandang Babi di Kelurahan Walian, Tomohon

Grafik di atas menunjukkan kelimpahan nyamuk bardasarkan hasil jumlah nyamuk yang tertangkap selama 12 jam dengan 3 kali ulangan. Jumlah total nyamuk yang tertangkap sebanyak 546 nyamuk yang terdiri dari 356 nyamuk genus Culex, 182 nayamuk Anopheles dan 8 nyamuk Armigeres. Nyamuk Culex paling banyak tertangkap pada jam 22.00 - 24.00 berjumlah 119 nyamuk dari total nyamuk Culex tertangkap 356 nyamuk. Nyamuk Anopheles paling banyak tertangkap pada jam 24.00 - 02.00 berjumalh 65 nyamuk dari total 182 nyamuk Anopheles, sedangkan nyamuk Armigeres paling banyak tertangkap (7 nyamuk) dari total 8 nyamuk yaitu pada jam 18.00 - 20.00.

Secara keseluruhan aktivitas nyamuk paling tinggi yaitu pada jam 22.00 -24.00, yang dapat dijelaskan dengan hasil tangkapan nyamuk yang paling banyak. Aktivitas nyamuk Culex paling nyamuk Armigeres aktif pada jam 18.00-20.00. Beberapa penelitian menemukan isolate virus Japanese encephalitis pada nyamuk-nyamuk Culex seperti Culex vishnui, Culex tritaeniorhyncus, Culex gelidus dan Culex fuscocephala (Van den Hurk et al, 2009; Van Peenen et al, 1975). Dengan demikian nyamuk Culex merupakan vector potensial terhadap penularan virus Japanese encephalitis pada ternak babi.

Faktor-faktor lingkungan biotik dan abiotik yang berpengaruh terhadap perkembangan nyamuk dalam kandang ternak babi, yaitu suhu sedang berkisar $26^{\circ} \mathrm{C}$ hingga $32,5^{\circ} \mathrm{C}$ dan kelembaban berkisar 56\% hingga 66\%. Penelitian Mutheneni et al (2013), menemukan bahwa pada kisaaran suhu $22^{\circ} \mathrm{C}-34^{\circ} \mathrm{C}$ dan kelembaban relative pada kisaran 42,7\% - 69,6\% merupakan kondisi yang baik bagi peningkatan kepadatan nyamuk. Penelitian lainnya mendapatkan bahwa ketergantungan pada kondisi cuaca, khusunya temperature, dimana nyamuk betina akan aktif mencari darah inang sepanjang malamsampai sebelum matahari terbit, seperti di bulan Agustus 1985 dengan kelembababn relative $33 \%$ dan suhu $16^{\circ} \mathrm{C}$, serta pada bulan penuh didapatkan populasi nyamuk tinggi di petang hari dan tengah malam (Mian L. S., et al, 1990). Factor lainnya adalah vegetasi yang tumbuh di sekitar kandang seperti tumbuhan bunga yang merupakan sumber makanan bagi nyamuk jantan, genangan air dalam bak penampungan di depan kandang yang merupakan tempat peletakan telur-telur dan perkembangan nyamuk.

\section{Kesimpulan}

1. Hasil penelitian menemukan 3 genera nyamuk dalam kandang ternak babi, yaitu: Culex, Anopheles dan Armigeres.

2. Populasi nyamuk Culex paling tinggi dan paling aktif pada jam 22.00-24.00. hal ini menunjukkan bahwa nyamuk Culex aktif mencari darah inangnya pada tengah malam hari.

3. Faktor-faktor lingkungan yang mendukung aktivitas dan perkembangan nyamuk dalam kadang babi, yaitu: suhu dan kelembaban relative, vegetasi sekitar kandang sebagai sumber makanan nyamuk jantan dan adanya genangan air dalam bak penanmpungan sebagai tempat peletakkan telur dan perkembangan nyamuk.

\section{Daftar Pustaka}

Lubis I. 1990. Masalah Penyakit Japanese Encephalitis di Indonesia. Cermin Dunia Kedokteran, No. 61: 24-27

Mallis A. 2004. Handbook of Pest Control. 9th ed. Departement of Entomology, The Pennsylvania State University, University Park, PA. GIE Media. Inc. ISBN:1-890561-01-0, chapt. 15, p. 883922.

Mian L. S., Mulla M. S., Axelrod H., Chaney J. D., and Dhillon M. S. 1990. Studies on The Bioecological Aspects of Adult Mosquitoes in The Prado Basin of Southern California. Journal of The Mosquito Control Association Vol. 6 No. 1: 64 - 71.

Sigit H. S., Koesharto F. X., Hadi U. K., Gunandini D. J., Soviana S., Wirawan I. A., Chalidaputra M., Rivai M., Priyambodo S., Yusuf S., Utamo S. 2006. Hama Permukiman Indonesia: Pengenalan, Biologi dan Pengendalian. Unit Kajian Hama Pengendalian Permukiman (UKPHP), Fakultas Kedokteran Hewan, Institut Pertanian Boogor. ISBN: 979-25-6940-5. Halaman 23-50.

Van den Hurk A.F., Ritchie S.A., and Mackenzie J.S. 2009. Ecology and Geographical Expansion of Japanese Encephalitis Virus. The Annual Review of Entomology, doi: 10.1146/annurev.ento.54.110807.090510:735.

Van Peenen P. F. D., Joseph S. W., Casals J., Saroso S., and See R. 1975. Arbovirus Antibodies in Indonesia at Malili, South Sulawesi (Celebes) and Balikpapan, East Kalimantan (Borneo). ISSN: 0003-4983 (print) 1364-8594 (online) Journal Homepage:

http:www.tandfonline.com/loi/ypgh19 